\title{
The Eye Lens as an Age Indicator in the Root Vole
}

\author{
Arne HAGEN, Nils Chr. STENSETH, \\ Eivind ØSTBYE \& Hans-Jørgen SKAR
}

\begin{abstract}
Hagen A., Stenseth N. Chr., Østbye E. \& Skar H. J., 1980: The eye lens as an age indicator in the root vole. Acta theriol., 25, 4: 39-50 [With 2 Tables \& 4 Figs.]

The method for estimating an animal's age based on the eye lens weight was applied for the root vole, Microtus oeconomus (P a 11 a s, 1776). A standard method for handling of lenses is suggested on the basis of various tests covering technical aspects such as type and length of fixation. The developed statistical model is compared with similar methods for estimating age, particularly for small rodents.

[Dept. of Beekeeping and Beebreeding, Agric. Univ. Norway, Semsveien 168, N-1370 Asker, Norway (AH), Zool. Inst., Univ. Oslo, P.O. Box 1050, Blindern, Oslo 3, Norway (NCS, EØ), Odvar Solbergs vei 94 , Oslo 9 , Norway (H-JS)].
\end{abstract}

\section{INTRODUCION}

Knowledge of an individual's age is essential to most population studies. For instance, reliable estimates of age are needed in order to construct life tables (cf. Em le n, 1973; K r e bs, 1978; or any other standard texts in ecology). In connection with a study of small rodent populations at Finse, Hardangervidda, Norway $\left(60^{\circ} 36^{\prime} \mathrm{N} ; 7^{\circ} 30^{\prime} \mathrm{E}\right.$ ) (see $\varnothing \mathrm{s}$ tb y e et al., 1975; $\mathrm{H}$ a g e $\mathrm{n}$ et al., 1975), we therefore aimed at constructing a convenient and reliable method for estimating the age of root voles (Microtus oeconomus), one of the dominant rodent species in the area.

It was reasonable to consider Lor d's (1959) method of using the weight of the eye lens as an age indicator, since this method has been successfully applied to other species of small rodents (e.g., M a r t in e t, 1966; Askaner \& Hansson, 1970; Østbye \& Semb-Johansson, 1970; Le Louarn, 1971; Adamczewska-Andrzejewska, 1971, 1973a, b; for review see Pucek \& Lowe, 1975). In particular the results of A d a m c z ewska-A ndrzeje ws k a (1971, 1973a) on striped field mouse (Apodemus agrarius) should be noted: She found that lens weight is the most reliable estimate of age. Tooth wear was shown to be a good measure of mean age for large samples, but 
showed a high degree of individual variation rendering it unsuitable for estimating age of individual specimens.

The present paper reports the application of the eye lens method to the root vole and its reliability in estimating age of animals caught in the field. As treatment of the lenses may influence the results, we also present a brief evaluation of technical details. Further, as many of the previous studies have paid little attention to statistical treatment of the data, and because some confusion exists, (e.g., G il b e r t, 1973b; Dapson, 1973), we also elucidate this aspect of the method in some detail.

\section{MATERIAL AND METHODS}

\subsection{Material}

Root vole stock from Finse were bred under controlled conditions in the laboratory. Eye lenses from 35 animals, aged 13 to 580 days were processed. In addition lenses from 11 animals marked as juveniles and therefore of known age, from 10 to 410 days when wrecaptured « as dead, were obtained from a study using live traps at Finse ( $\mathrm{H}$ a g e $\mathrm{n}$ et al., 1975). In order to evaluate the fixation procedure, a comparable sample of root voles were obtained by snap-trapping in the same area.

\subsection{Treatment of the Lenses}

In our standard procedure (see also Section 4) the lenses were fixed in $4 \%$ formaldehyde $(40 \%$ : water $=1: 9)$ for one week, then dissected out and dried in an incubator at $80^{\circ} \mathrm{C}$ for one week, and weighed immediately with $0.01 \mathrm{mg}$ accuracy. We summed the weight of the two lenses. In the rare cases where one lens was damaged, the weight of the remaining one was doubled. In the tests of various fixation procedures, one lens of a pair was subjected to the standard procedure whereas the other lens was subjected to an alternative treatment.

\subsection{The Statistical Model}

Our purpose is to arrive at an estimate of age, $A$ (in days), from knowledge of the combined lens weight, $W$ (in $\mathrm{mg}$ ), i.e.

$$
A=f(W)
$$

From Eq. (1), it can be seen that we want to find the regression of $A$ on W (terminology as in Draper \& Smith 1966). Myers \& Gilbert (1968) and Gilbert (1973a, b) state categorically that this is the only valid regression. However, $A$, as given in our material and presumably in most other equivalent materials, in a discrete non-random variable. Thus it cannot be used as the dependent variable in the regression analysis as suggested by M y ers \& Gil bert (1968) and Gilbert (1973a, b). Nevertheless, $A$ may be used as an independent variable ( $\mathrm{S} v$ e r d r u p, 1964). The regression of $W$ on $\mathrm{A}$ is given as 


$$
W=f^{-1}(A) .
$$

The following must be satisfied if regression is to be applied appropriately: The error term is defined as $e=W_{\text {obs }}-W_{\text {pred }}$, where $W_{\text {obs }}$ and $W_{\text {prec }}$ are the observed and predicted values of the dependent variable $(W)$ for a given value of the independent variable $(A)$. This error term, $e$, must be distributed normally around zero with a constant variance (cf. Draper \& S mith, 1966; or S tenseth, 1977 for a non-technical treatment). No similar requirement exists for the independent variable, A. Daps on (1973) erroneously seems to imply this, even referring to standard texts such as Steel \& Torrie (1960) and Sokal \& Rohlf (1969).

This non-symmetry with respect to assumptions for $A$ and $W$ may in certain cases restrict the definition of what is to be the dependent and what the independent variable. The problem of estimating age from lens weight is such a case.

Following for instance, Dapson \& Irland (1972), we have assumed the following functional relationship or model:

$$
W=a+b \cdot \log (A)
$$

where $a$ and $b$ are two parameters to be estimated from data; their least square estimates are denoted $\hat{a}$ and $\hat{b}$ in the following. Substituting $X=\log (A)$ and $\mathrm{Y}=\mathrm{W}$ and assuming a normally distributed variable, $e$, we have the following statistical model:

$$
Y=a+b \cdot X+e .
$$

As pointed out in many statistical texts, but nevertheless often forgotten, model (4) is only valid for $x$-values inside its domain of definition, i.e. only for the range of $x$-values used for finding $\hat{a}$ and $\hat{b}$. Note that due to our estimation problem being of the sinverse prediction " type (cf. $\mathrm{Z}$ a r, 1974), this domain is defined along the vertical axis in Fig. 2, and not as commonly defined, along the horizontal axis. In the present study on the root vole we have applied $x$-values in the open interval 21-365 days. These limits have been chosen on the basis of residual analysis (e.g., Draper \& S mith, 1966; see also Stenseth, 1977).

By inverting the function given by Eq. (2), we arrive after some rearrangement at

$$
\frac{W-\hat{a}}{\grave{b}}
$$

having the equivalent form

$$
\hat{X}=\frac{Y-\hat{a}}{\hat{b}}
$$

Model (5) gives a point estimate of $A$ for a given W. A corresponding intervalestimate for individuals is found by (cf. Goldstein, 1967; Dapson \& I r la nd, 1972):

$$
L=\frac{1}{1-g}\left[\hat{X} \pm \frac{t \cdot s_{y x}}{\hat{b}} \sqrt{1+\frac{1-g}{n}+\frac{(\hat{X}-\bar{X})^{2}}{s s_{x}}}\right]
$$

where $n$ is the number of observations used for finding $\hat{a}$ and $\hat{b}$ in Eq. (4), $t$ is the $5 \%$-fractile in the Student distribution with n-2 degrees of freedom, and $\bar{X}$ is the observed mean. Furthermore, 


$$
\begin{gathered}
s s_{x}=\Sigma(X-\bar{X})^{2} \\
s_{y x}^{2}=\frac{\Sigma(Y-\hat{Y})^{2}}{(n-2)}
\end{gathered}
$$

and

$$
g=\frac{t^{2} \cdot s^{2} y x}{b^{2} \cdot s s_{x}}
$$

Having found $L$ as given by Eq. (7), $10 \mathrm{~L}$ gives an interval estimate $\left(\AA_{l}, A_{u}\right)$ for age.

If the interval estimate for the mean is desired, it may be found by subtracting 1 from the expression inside the square root sign in Eq. (7) (Goldstein, 1967; Dapson \& Irland, 1972). Other formulae can be found (e.g., Eisenhart, 1939; Blis s, 1967; Snedecor \& Cochran, 1967; Sokal \& Rohlf, 1969; $\mathrm{Zar}$, 1974). Although the formulae given by these authors differ somewhat in detail, they all yield similar results (R. W. D a p s o n pers. comm.).

\section{RESULTS}

\subsection{Fixation}

The results of the lens fixation tests are shown in Fig. 1. There is no significant difference between the weights of a pair of lenses fixed in $4 \%$ formaldehyde for one week (Fig. $1 \mathrm{~A}$; Wilcoxon or Mann-Whitney two-sample rank test; $\mathrm{O}$ we $\mathrm{n}, 1962)$. The same result has been found in earlier studies (e.g., Lord, 1959; B r o e k h u i z e n, 1973).

When collecting organs from small rodents for histological purposes, the samples were usually transferred to $70 \%$ alcohol after fixation (Ø $\mathrm{s} \mathrm{tb}$ y e et al., unpubl.). In pairs where one of the lenses was stored in $70 \%$ alcohol for one week after both had been fixed in $4 \%$ formaldehyde for one week, the alcohol-stored lenses were almost significantly lighter at 5\%-level (Fig. 1B).

Lenses fixed in $4 \%$ formaldehyde for one week versus four weeks, showed no significant difference, although there was a slight tendency for the four-week lenses to be heavier (Fig. 1C). This may represent a general phenomenon: If organs, including eye lenses, are stored in formaldehyde for long periods, they increase in weight ( $\mathrm{Puce} \mathrm{k}, 1967)$. This is probably due to the formation of paraformaldehyde in the tissues. In lenses fixed in $4 \%$ formaldehyde versus $10 \%(40 \%$ : water $=$ $1: 3$ ), the $10 \%$-lenses are significantly heavier (Fig. 1D). In addition, it is known that frozen lenses are significantly lighter than those freshly fixed (Østbye \& Semb-Johansson 1970; their Fig. 2; Broekhuizen, 1973; his Fig. 1C). 

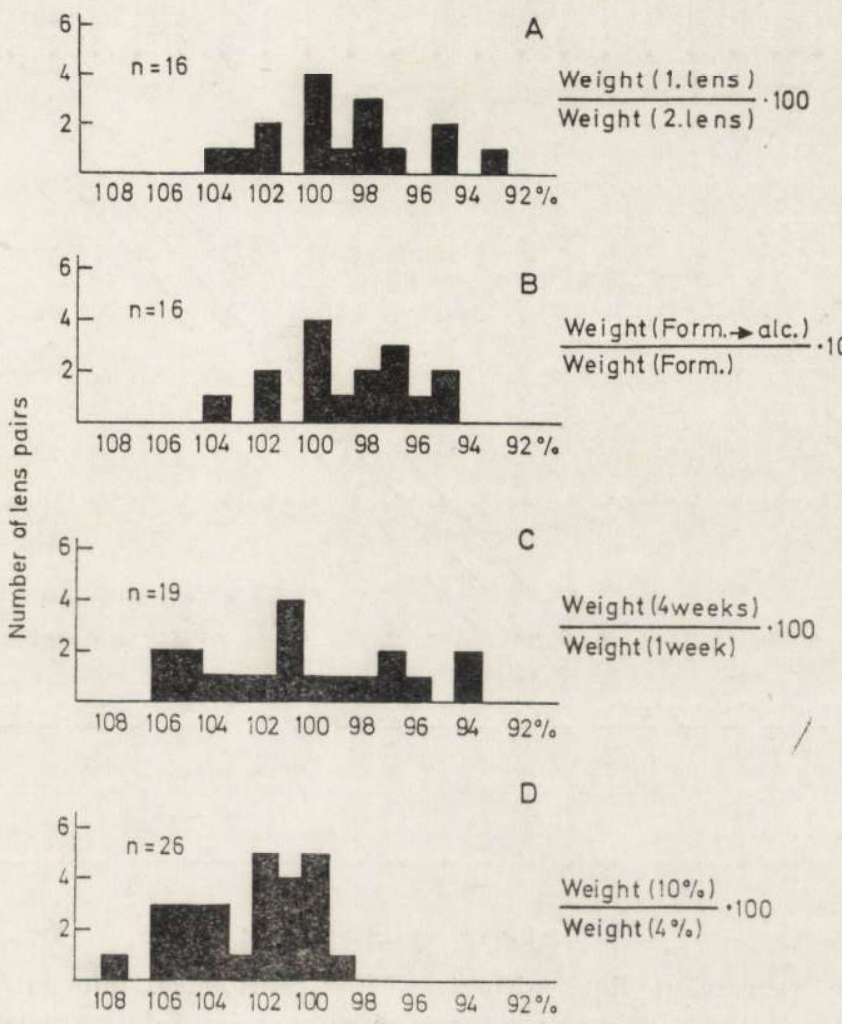

Fig. 1. The differences between weights of lenses subjected to different treatments. A: Both lenses fixed for one week in $4 \%$ formaldehyde. No systematical difference.

B: Both lenses fixed in $4 \%$ formaldehyde for one week. One then stored in $70 \%$ alcohol for one week. Alcohol stored lenses almost significantly lighter at $5 \%$ level.

C: One lens fixed in $4 \%$ formaldehyde for one week, the other for four weeks. No systematical difference.

D: One lens fixed in $4 \%$ formaldehyde for one week, the other in $10 \%$ for one week. $10 \%$-lenses significantly heavier.

\subsection{The Regression Line}

The regression line together with its $95 \%$ confidence interval for individual predictions is shown in Fig. 2 (cf. Table 1). Note that the $x$ and $y$ axes are interchanged for reasons given in Section 2.3. Data points for animals younger than three weeks or older than one year, not included in the regression analysis, are also shown. Further, only data from laboratory animals are included in the regression analysis. On the basis of the statistics given in Table 1 it is seen that $96 \%$ of the variation is explained by the performed regression. In Fig. 2 


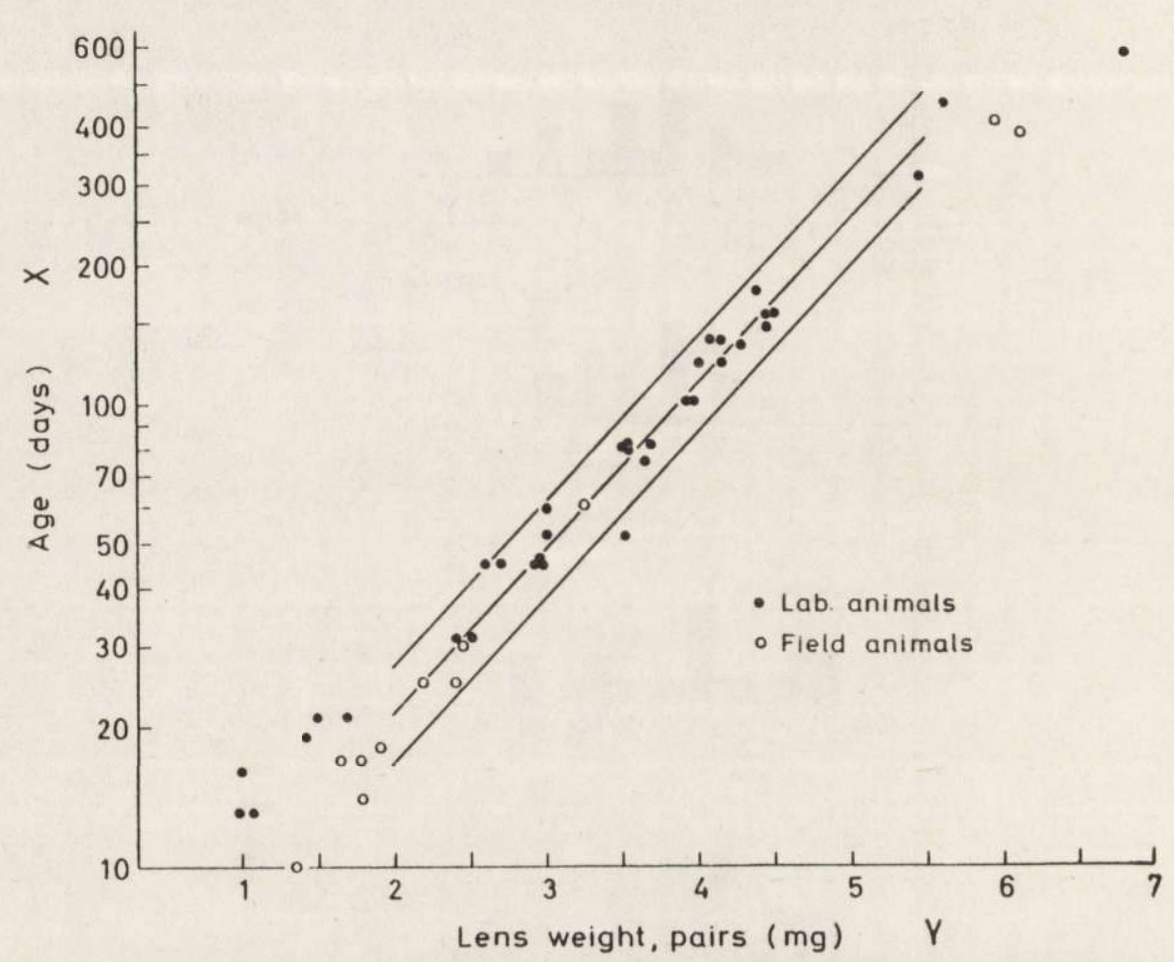

Fig. 2. The regression line with its $95 \%$ confidence interval for individual predictions for the root vole (Microtus oceonomus). Solid dots are laboratory-reared animals, stocked from Finse; open dots are wild animals caught at Finse.

Table 1

Estimated parameter values entering model (3) and other necessary quantities entering the formula for the confidence limits (Eq. (7)). $S_{x}$ is the sum of $x$, and $t$ is the $95 \%$ Student fractile with $n-2$ degrees of freedom. Other symbols are defined in Sect. 2.3.

\begin{tabular}{|c|c|c|c|c|c|c|c|c|}
\hline$\hat{a}$ & $\hat{b}$ & $\mathrm{n}$ & $r$ & $s_{y x}$ & $s_{x}$ & $s s_{x}$ & $t$ & Species and authors \\
\hline-1.729 & 2.799 & 31 & 0.983 & 0.140 & 57.949 & 110.661 & 2.045 & $\begin{array}{l}\text { Microtus oeconomus } \\
\text { This work }\end{array}$ \\
\hline-1.378 & 2.075 & 144 & 0.932 & 0.198 & 261.332 & 482.969 & 1.977 & $\begin{array}{l}\text { Lemmus lemmus } \\
\text { Østbye \& Semb- } \\
\text { Johansson (1970) }\end{array}$ \\
\hline-227.6 & 168.224 & 72 & 0.987 & 9.756 & 164.818 & 386.520 & 1.994 & $\begin{array}{l}\text { Sylvilagus floridanus } \\
\text { Lord (1959) }\end{array}$ \\
\hline
\end{tabular}

are also depicted data points for field animals. Notice that these do not show any sign of deviation from laboratory animals. This indicates that our method may be applied for any reasonable length of age span for root voles. Thus, this is much better than what is possible for, e.g., hares (Lepus europaeus) (A n d e r s o n \& J e n s e n, 1972). 
Table 2 shows the $95 \%$ confidence limits of predicted ages $X$ (or $A$ ) for mean predictions and for individual predictions with given lens weight. For convenience the table covers the interval from 25 to 375 days.

It should at this point be emphasized that for most applications of this method in population studies, the seasonal changes in lens growth discussed by $\mathrm{Schwarz}$ et al. (1964) will have no important effects on the conclusions being reached (e.g., S tens eth et al., 1979).

Table 2

95 per cent confidence limits about predieted ages for $M$. oeconomus. $\hat{Y}$ values are expressed in $\mathrm{mg}$ lens weight (pairs). Ages $(\hat{X})$ are in days.

\begin{tabular}{|c|c|c|c|c|c|}
\hline \multirow{3}{*}{$\begin{array}{c}\text { Lens } \\
\text { weight } \\
\text { Y }\end{array}$} & \multirow{3}{*}{$\begin{array}{c}\text { Age } \\
\hat{X}\end{array}$} & \multicolumn{2}{|c|}{ Mean predictions } & \multicolumn{2}{|c|}{ Individual predictions } \\
\hline & & Lower age & Upper age & Lower age & Upper age \\
\hline & & limit & limit & limit & limit \\
\hline 2.18 & 25 & 24 & 26 & 20 & 32 \\
\hline 3.03 & 50 & 48 & 52 & 39 & 64 \\
\hline 3.52 & 75 & 72 & 78 & 59 & 95 \\
\hline 3.87 & 100 & 96 & 104 & 79 & 127 \\
\hline 4.14 & 125 & 120 & 131 & 98 & 159 \\
\hline 4.36 & 150 & 144 & 157 & 118 & 191 \\
\hline 4.55 & 175 & 168 & 183 & 138 & 222 \\
\hline 4.71 & 200 & 192 & 209 & 157 & 254 \\
\hline 4.85 & 225 & 215 & 235 & 177 & 286 \\
\hline 4.98 & 250 & 239 & 261 & 197 & 318 \\
\hline 5.10 & 275 & 263 & 288 & 217 & 350 \\
\hline 5.20 & 300 & 287 & 314 & 236 & 381 \\
\hline 5.30 & 325 & 311 & 340 & 256 & 413 \\
\hline 5.39 & 350 & 335 & 366 & 376 & 445 \\
\hline 5.48 & 375 & 359 & 393 & 295 & 477 \\
\hline
\end{tabular}

\section{RECOMMENDATION}

On the basis of the results given in Section 3.1., we recommend the following treatment of lenses to be followed in such studies.

1. Extract eyes from fresh animals. Avoid decomposition and desiccation.

2. Transfer the eyes to $4 \%$ formaldehyde. Careful puncture of the eyeball facilitates fixation.

3. After fixation for one week, dissect out the lens from the eyeball, remove ligaments and dry the lenses to constant weight in an oven at $80^{\circ} \mathrm{C}$ ( $\mathrm{L}$ or d, 1959; and later workers). For small rodents five days will suffice.

\section{COMPARISON WITH OTHER METHODS}

It has been suggested that lens weight is not a suitable method for estimating age in small mammals because wide confidence limits are presumed to result (e.g. Daps on \& Irland, 1972). Thus, methods based on biochemical changes within the lens have been recommended 
(e.g., Da pson et al., 1968; D a ps on \& I r land, 1972). However, to our knowledge, no direct comparison of these different methods has: been undertaken. Except for the fact that our work is on a different. species than that of Dapson \& Irland (1972) who relied on biochemical methods, our results are directly comparable. The mean age in D a p s on \& Ir land's (1973) material on old-field mouse (Peromyscus polionotus) was approximately 350 days. The predicted $95 \%$ confidence interval for mean predictions about this age represents $8.6 \%$ of the mean age (Dapson \& Irland 1972; their Table 1). In our material, 75 days was the mean age. As can be seen from Table 2, the $95 \%$ confidence interval represents $8.0 \%$ of the mean age. The corresponding figures for individual predictions are $75 \%$ and $48 \%$ for Dapson anr' Irland's study and our own (Table 2), respectively. This

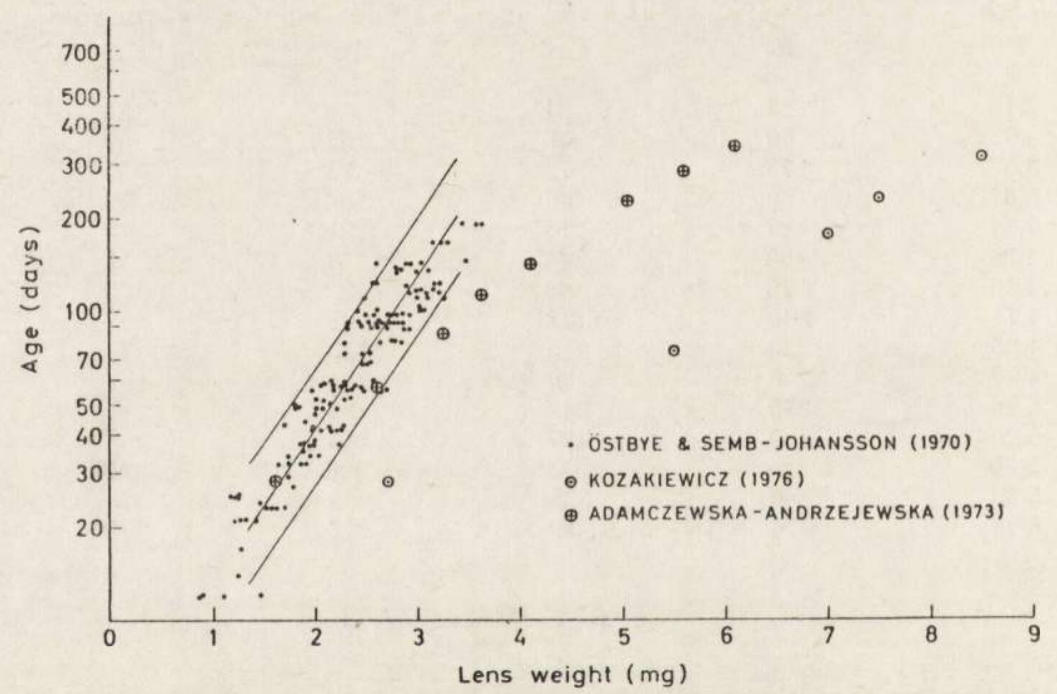

Fig. 3. Data for various small rodent species plotted in order to test the applicability of model (3). The following data sets are plotted:

$\varnothing \mathrm{s}$ tb y e \& S e mb-Johans s on's (1970) data on Norwegian lemming (Lemmus lemmus). Regression line with its $95 \%$ confidence interval for individual predictions is depicted. Parameters in the corresponding regression model are given in Table 1. Oniy those lenses fixed in $4 \%$ formaldehyde are depicted and applied in regression analysis. Of those depicted, only animals older than 20 days are included in the analysis.

Approximate data from Adamczewska-Andrzejewska (1973b) on Microtus arvalis and from $\mathrm{Kozakiewicz}$ (1976) on Clethrionomys glareolus are sketched.

comparison suggests that the lens weight method may be as good as the tyrosine method of Dapson \& Irland (1972). Further, as the lens weight method is technically simpler, it may be preferred for most routine work. 
Model (3) was applied by Da p s on \& I r l a n d (1972). Their data did not demonstrate any systematic deviation from the model. Neither are such deviations found in our material.

Østbye \& Semb-Johansson (1970) in a study on the Norwegian lemming (Lemmus lemmus) assumed no specific model. However, plotting their data on semilog paper (Fig. 3) it is seen that no obvious deviation from model (3) results. Therefore, on the basis of their original data, we have estimated the parameters in model (3) (cf. Table 1). For

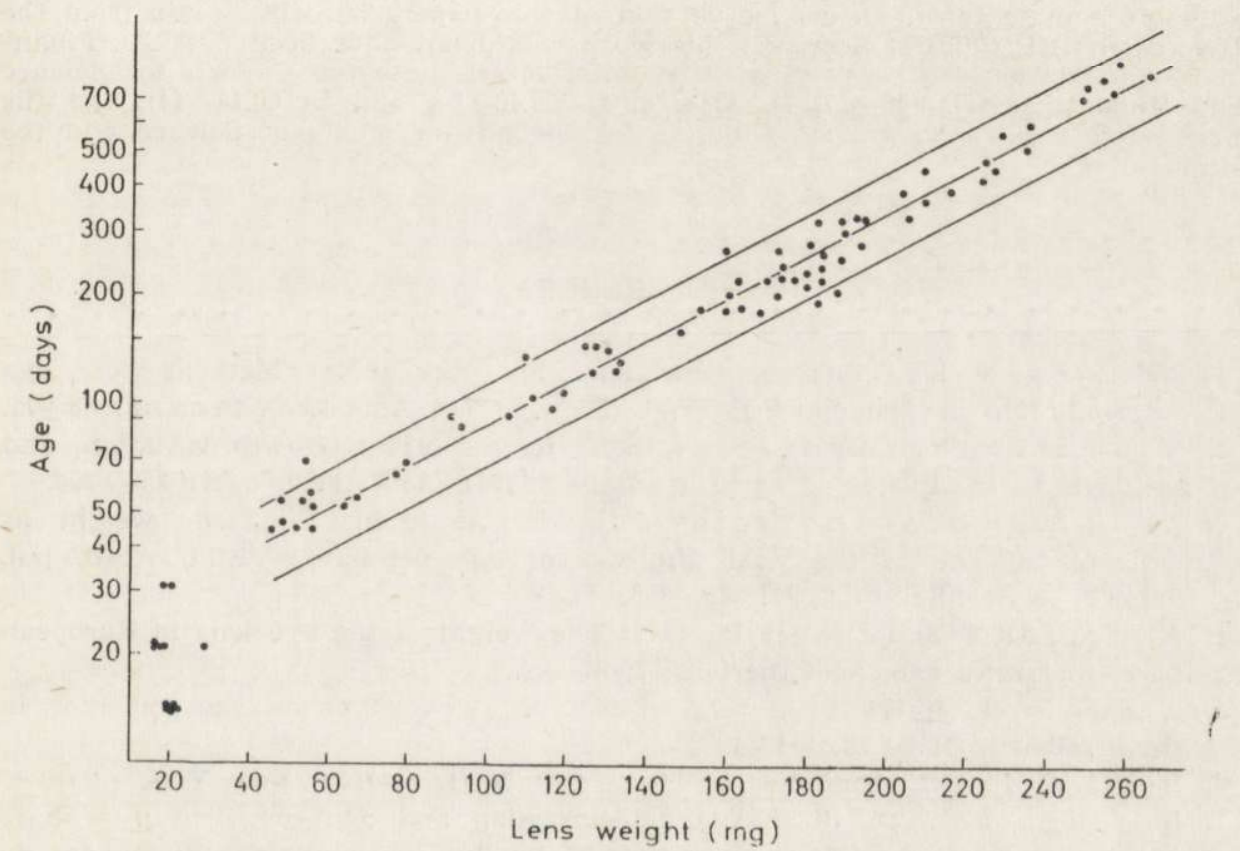

Fig. 4. Lord's (1959) data on cottontail rabbit (Sylvilagus floridanus) plotted in order to test the applicability of model (3). The regression line with its $95 \%$. confidence interval for individual predictions is depicted (Table 1).

this analysis we have, as in the present study, applied only animals older than 20 days. No specific model was assumed by Lor d (1959) in his study on the cottontail rabbit (Sylvilagus floridanus). However, using his data for animals older than 40 days, we estimated the parameters in model (3) (Table 1) and demonstrated that no such deviations can be found in Lord's (1959) data either (Fig. 4). K o z a k i e w i c z (1976) in a study on the bank vole (Clethrionomys glareolus) assumed two linear models defined over two complementary ranges, the border between which was decided somewhat arbitrarily. Plotting all Kozakiewicz's data, taken approximately from his graph, on semilog paper 
(Fig. 3) it is seen that no obvious deviation from model (3) results. Analyzing Adamczewska-Andrzejewska's (1973b) data for the European common vole (Microtus arvalis) in a similar way, a systematic deviation is, however, found (Fig. 3).

Altogether, this demonstrates that model (3) is applicable for several species. Adamczewska-Andrzejewska's study demonstrates, however, that model (3) is not generally valid.

Acknowledgements: G. Kneisel and I. Tambs-Lyche are thanked for valuable technical assistance. P. H. Enckell and L. Hansson are thanked for providing valuable comments on an earlier version of this paper. Without grants from the Norwegian IBP (PT/UM Sections) this work would not have been possible. Financial support was a'so received from the Norwerian Rese-rch Council for Science and Humanities (D. $600-17$, D. $602-20$, D. $60.46-04$, and D. $60.46-44$ ), and the Fridtjof Nansen's and affiliated Funds for the advancements of Science and the Humanities.

\section{REFERENCES}

1. Adamczewska-Andrzejewska K. A., 1971: Methods of age determination in Apodemus agrarius (Pallas 1771). Ann. Zool. Fenn., 8: 68-71.

2. Adamczewska-Andrzejewska K. A., 1973a: Growth variation, and age criteria in Apodemus agrarius (Pallas 1771). Acta theriol., 18: 353-394.

3. Adamczewska-Andrzejewska K. A. 1973b: The lens weight as indicator of age of the wild Microtus arvalis population. Bull. Acad. pol. Sci., Cl. II, Ser. Sci. biol., 21: 331-336.

4. Andersen J. \& Jensen B., 1972: The weight of the eye lens in European hares of known age. Acta theriol., 17: 87-92.

5. Askaner T. \& Hansson L., 1970: The eye lens as an age indicator in small rodents. Oikos 18: 151-153.

6. B li s S C. I., 1967: Statistics in biology, 1, McGraw-Hill: New York.

7. Broekhuizen S., 1973: Age determination and age composition of hare populations. Actes du Xe Congres de L'Union Internationale des Biologistes du Gibier: 477-489. Office National de la Chasse, Paris.

8. Dapson R. W. 1973: "Letter to the editor". J. Mammal., 54: 804.

9. Daps on R. W. \& I r land J. M., 1972: An accurate method of determining age in small mammals. J. Mammal., 53: 100-106.

10. Dapson R. W., Otero J. G. \& Holloway W. R., 1968: Biochemical changes with age in the lenses of white mice. Nature, 218: 573.

11. Draper N. R. \& S mith H., 1966: Applied Regression Analysis. Wiley \& Sons, Inc.

12. E is e $\mathrm{nhart}$ C., 1939: The interpretation of certain regression methods and their use in biological and industrial research. Ann. math. Statist., 10: 162-186.

13. Emlen J. M., 1973: Ecology: an evolutionary approach. Addison-Wesley Publ. Co. Reading.

14. Gilbert N. E., 1973a: Biometrical interpretation. Oxford Univ. Press: Oxford.

15. G i lbert N. E., 1973b: „Letter to the editor” J. Mammal., 54: 560.

16. Goldst e in A., 1967: Biostatistics. Macmillan, N. Y. 
17. Hagen A., Østbye E. \& Skar H.-J., 1975: Population energy budget of the root vole (Microtus oeconomus (Pall.)) in a high mountain habitat, Hardangervidda. Ecol. Studies, 17: 283-299.

18. Kozakiewicz M., 1976: The weight of the eye lens as the proposed age indicator of the bank vole. Acta theriol., 21: $314-316$.

19. Krebs J., 1978: Ecology: the experimental analysis of distribution and abundance. (2nd ed.). Harper and Row, New York.

20. Le L ou a r n H., 1971: Determination de l'age par la pesée des cristallins chez. quelques especes de rongeurs. Mammalia, 35: 636-643.

21. L ord Jr., R. D., 1959: The lens as an indicator of age in cottontail rabbits. J. Wildl. Mgmt., 23: 358-360.

22. Martinet L., 1966: Determination de l'age chez le campagnol des champs (Microtus arvalis Pallas) par la pesée du cristallin. Mammalia, 30: 425-430.

23. Myers K. \& Gilbert N., 1968: Determination of age of wild rabbits in Australia. J. Wildl. Mgmt., 32: 841-849.

24. $\varnothing \mathrm{stbye}$ E. \& Semb-Johansson A., 1970: The eye lens as an age indicator in the Norwegian lemming (Lemmus lemmus (L)). Nytt Mag. Zool., 18: $239-243$.

25. Ø s t b y e E., Berg A., Blehr O., Espeland M., Gaare E., Hagen A., Hesjedal O., Hågvar S., Kjelvik S., Lien L., Mysterud I., Sandhaug A., Skar H.-J., Skartveit A., Skre O., Skogland T., Solhøy T., Stenseth N. C. \& Wielgolaski F. E., 1975: Hardangervidda, Norway. Ecol. Bull. (Stockholm), 20: 225-264.

26. O we n D. B., 1962: Handbook of statistical tables. Addison-Wesley. Reading, Palo Alto, London.

27. Pucek M., 1967: Changes in the weight of some internal organs of Micromammalia due to fixing. Acta theriol., 12: 545-553.

28. Pucek Z. \& Lowe V. P. W., 1975: Age criteria in small mammals. [In: Golley, F. B., Petrusewicz K., and Ryszkowski L. (eds.). "Small mammals: their productivity and population dynamics"]. Camb. Univ. Press: 55-72. Cambridge.

29. Schwarz S. S., Pokrovski A. V., Istchenko V. G., Olenjev V. G., Ovtschinnikova N. A. \& Pjastolova O. A., 1964: Biological pecularities of seasonal generations of rodents, with special reference to the problem of senescence in mammals. Acta theriol., 8: 11-43.

30. Snedecor G. W. \& Cochran W. G., 1967: Statistical methods. The Iowa State Univ. Press, Ames.

31. Sokal R. R. \& Rohlf F. J., 1969: Biometry. Freeman and Co. N.Y.

32. Ste el R. G. D. \& Torrie J. H., 1960: Principles and procedures of statistics. McGraw-Hill, N.Y.

33. Sten seth N. C., 1977: Forecasting of rodent outbreaks: models and the real world. EPPO Bull., 7: 303-315.

34. Stenseth N. C., Hagen A. \& $\varnothing \mathrm{stb}$ y e E., 1980: Is it useful to be able to age small mammals: some biological implications of knowing an animal's age. Msc.

35. Sverdrup E., 1964: Lov og tilfeldighet, 1, Universitets-forlaget: Oslo. (English translation 1967: Laws and Chance Variations, vol. 1. North Holland Publ. Co., Amsterdam).

36. Z a r J., 1974: Biostatistics. Prentice-Hall, Co.

Accepted, October 31, 1979.

4 - Acta Theriologica 
A. Hagen et al.

Arne HAGEN, Nils Chr. STENSETH, Eivind ØSTBYE i Hans-Jørgen SKAR SOCZEWKI JAKO WSKAŹNIK WIEKU U MICROTUS OECONOMUS

\section{Streszczenie}

Oznaczanie wieku u $M$. oeconomus przeprowadzano w oparciu o ciężar soczewek. Standardową metodę postępowania $\mathrm{z}$ soczewkami wypracowano na podstawie różnych testów uwzględniających takie aspekty techniczne jak rodzaj i długość utrwalania (Fig. 1). Model statystyczny porównywano $\mathrm{z}$ podobnymi metodami oceny wieku, szczególnie u drobnych gryzoni (Fig. 3 i 4; Tab. 1). Wzrost ciężaru soczewek w zależności od wieku norników oraz zróżnicowania indywidualne przedstawiono w Tabeli 2. 